\title{
A Study on College Students' Political Engagement Based on the Intervention of Curriculum*
}

\author{
Jun $\mathrm{Hu}$ \\ School of Marxism \\ Zhejiang University \\ Hangzhou, China 310028 \\ Shen Junru Law School \\ Hangzhou Normal University \\ Hangzhou, China 310024
}

\author{
Lifeng Ma \\ Shen Junru Law School \\ Hangzhou Normal University \\ Hangzhou, China 310024
}

\begin{abstract}
The study on enhancement of college students' political engagement can contribute to changing the political apathy of contemporary college students. The assessment on curriculum effects is conducted through constructing and implementing the college theme CYL day activity curriculum based on improvement of college students' political engagement and adopting the method of empirical study. It is found in the study that: the students participating in the theme day activity curriculum possess relative high inner sense of political efficacy; focus more on the politics and public affairs; show stronger interests; possess better conservation comprehension ability; and can apply the comprehension orientation in the political communication process. This further shows that the curriculum of CYL Day activity can promote the political engagement of college students and expand the new vision for the study on citizenship education for college students.
\end{abstract}

Keywords—political engagement; intervention of curriculum; college students

\section{INTRODUCTION}

The studies about young people political engagement, especially the studies on college students' political engagement have received the attention of broad researchers and educators. The college students political engagement refers to the activities where the college students who have citizenship participate in political life and express political view point on the basis of understanding state politics and social conditions through certain measures or procedures so as to impact government decisions or political system operation [1]. For the broad colleges, except for contributions to the economic and cultural development of themselves, they also undertake the task of giving college students the opportunity of experiencing democratic authenticity, while such kind of democratic authenticity origins from group learning, working and living conditions. Since 1990s, when the engagement awareness, engagement practice and engagement ability of domestic college students are continuously enhanced, the situation of

*Fund program: Phased Achievements of the Special Task Program of Ministry of Education in 2016 for Humanities and Social Sciences Study (college ideological and political works) "Study on the Cultivation of College Students Legal Ideas under the Background of Micro Era" (Y201533478). political apathy is increasingly becoming the outstanding feature of contemporary college students' political engagement. The negative impacts brought by political apathy of contemporary college students on democratic political construction, stable social development and the healthy growth of college students are much greater than the positive effects. Therefore, promotion of college students' political engagement is an important task in the ideological and political education tasks of colleges.

The foreign studies on promotion of young people political engagement are mostly the subjective engagement oriented and curriculum intervention oriented. Many colleges focus on how to deepen its community services and service learning programs and finally lay the foundation for students to step into society in the future and become the citizens with senses of engagement and responsibility through the four-year college careers (Hollander, 2011)[2]. The colleges ensure students to indirectly participate in politics through service learning and other community engagement activities (Gillmor, 2012)[3]. While some college educators think that more citizens with political engagement can be cultivated through formal or informal education plans which focus on the discussion on appropriate issues and issues related to the those who will possibly become global citizens in the future (Simpson, 2013)[4]. There are certain intervention measures aiming at development of college students political engagement promoting their ability of participation in citizen affairs (Klofstad, 2010)[5]; set up the discussion section based on community conditions in general education curriculum (Schamber, 2008)[6]; combine the volunteer activities with election experience (Mariani, 2009)[7].

From the study method, the domestic studies on college students political engagement mainly focus on investigation study and literature study to discuss the current situations of college students political engagement and engagement measures (Xu Hua, 2010; Wu Taisheng, 2010; Tang Guozhan, 2010)[8][9][10]; from the study contents, there are many studies focusing on the online political engagement of college students which conduct explorations on the aspects including current engagement situations, engagement features and guidance mechanism, etc. (Zou, Jingqin, 2010; Sun Dawei, 
2012; Ji Haiju, 2014)[11][12][13]. It is not hard to see that although the domestic studies on college students political engagement have obtained rich achievements in recent years, they mostly take investigation studies and theoretical exploration as orientation and propose scientific and systematic practice mechanism from the developed study achievements while there lacks the curriculum intervention studies similar with those foreign studies.

What's more, the unit of college CYL Day activities is based on basic class Youth League branches so as to develop the basic activities with distinct themes and full contents[14]. In term of its essence, the activity design, development and assessment can all comply with the "four-element" features for curriculum design. The feature of "curriculum" in college CYL Day activities enables the study to possess the possibility on aspects of theory and real practice which also respond to the requirements on "reform and innovation of league works and activities and the construction of basic organizations: in the current Reform Scheme of the Central Committee of the Communist Young League. Whereby this study clarifies this kind of subjective engagement and curriculum intervention oriented CYL Day activities through construction and implementation of the college theme CYL Day activity curriculum based on college students political engagement and adopting the method of empirical study to conduct assessment to the curriculum effects which is one of the effective path for construction of college students political engagement.

\section{STUDY PROCESS}

\section{A. Study Object}

Take two Freshman classes (one as experimental class and another one as control class) in the full time undergraduates of $\mathrm{XX}$ school of XX college where the control class has 40 students (male: 18; female: 22 ) with the age of $18 \pm 0.22$; the experimental class has 41 students (male: 17; female: 24) with the age of $18 \pm 0.19$.

\section{B. Study Design and Contents}

This study adopts the design of control experiment. The experimental class holds the theme CYL Day activity per week with the term of 7-week times aiming at promotion of college students political engagement degree and each time takes $1.5 \mathrm{~h}$. The 7-week time theme CYL activity curriculum is implemented by the same teacher. There is no such theme CYL Day activity in control class. Each student under test in experimental group will completely receive 7 times of CYL Day activities; the questionnaire survey is double-blind survey.

The content design of theme CYL Day activities based on promotion of college students political engagement is mainly based on the four factors impacting college students political engagement [15] and is developed in the forms including classroom discussion, simulation drilling and on-spot debates, etc so as to build the activity environment aiming at promoting students to be pleased to share the political opinions. See "Table I" for the details of curriculum content design. By taking the theme of "political text discussion" as example, the teachers will select the Report on the Work of the Government of 18th National Congress of the Communist Party of China and 19th National Congress of the Communist Party of China in advance and combine with the learned contents in "reading strategy analysis" of second week, let the students participating in the theme CYL Day activity conduct in-depth discussions in the unit of groups on the similarity and difference between the reports of 18th National Congress of the Communist Party of China and 19th National Congress of the Communist Party of China and finally express their opinions in the form of group presentation. At the same time, require the students participating in the CYL Day activity to actively seek for a communication partner after completion of activities to make the conversation with the theme of "My Opinions on 19th National Congress of the Communist Party of China" and make related records as the contents to be shared on the next theme CYL Day activity.

TABLE I. CONTENTS OF THEME CYL DAY ACTIVITY CURRICULUM

\begin{tabular}{ll}
\hline \multicolumn{1}{c}{ Week Time } & \multicolumn{1}{c}{ Curriculum Content } \\
\hline First week & Political poetryandprose analysis \\
Second week & Reading strategy analysis \\
Third week & Collection of political information \\
Fourth week & Classic political text discussion \\
Fifth week & Group discussion based on text \\
Sixth week & On-spot political theme discussion and presentation \\
Seventh week & Introspection and conversation \\
\hline
\end{tabular}

\section{Study Tool}

The questionnaire for the study used for assessment on the impacts of implementation of theme CYL Day activity on the student political engagement consists of three subscales (the question items all adopt five-point scoring method) with total 19 question items.

The first subscale is the college student political engagement scale with total five question items (its internal coefficient of concordance is 0.72 ), where "political attention" includes two question items separately being "Are you interested in politics and political affairs" and "How is the degree of attention of you on political and public affair news"; the "degree of satisfaction of political engagement skills" includes one question item which is "are you satisfied with you own abilities of understanding the political opinions of others"; the "self-confidence degree of engagement in political conversation" includes one question item which is "are you confident of your own engagement in the conversation full of politics"; the "inner political efficacy" also includes one question item which is "do you agree with the opinion that you have played roles during the political process."

The second part is the scale used for exploring the tendency (comprehension type/strategy type) of students to use the contents learned in political conversation with total 9 question items. Thereinto, the "comprehension type" means that the political conversations developed are mainly used for understanding the political stands of others so as to seek for common sense of comprehension or communication as the objective which include "do you agree with the opinion that it is important to listen to others"; "do you agree with the opinion that it is important to learn from others in the political conversation"; "do you agree with the opinion that it is of great 
importance to learn others to use the political communications as the certain measures to promote the intimacy among people" and other three question items (its internal coefficient of concordance is 0.65 ); the "strategy type" means to use strategies in political conversation to achieve the goal of convincing others, which includes three question items including "do you agree with the opinion that the political conversation is to gain advantages"; "do you agree with the opinion that the political conversation is to let the other party do what you want", etc (its internal coefficient of concordance is 0.51 ).

The third part is used to examine the political knowledge reserve and accumulation of students which is designed with five question items through selecting the current hot political affairs including "which party is the current ruling party of America", "who is the current Prime Minister of UK" and "how many years are the tenure of each term of National People's Congress, etc., one point for each correct answer; 0 point for wrong answer.

\section{Study Hypothesis}

This study aims to explore whether it will cause positive impacts on the college student political engagement through curriculum intervention from the perspective of CYL Day activity curriculum which mainly sets forth from the verification on the following four study hypothesis:

Study hypothesis I: the students receiving curriculum intervention possess relatively high inner political efficacy.

Study hypothesis II: the students receiving curriculum intervention focus much more on the political and public affairs.

Study hypothesis III: the students receiving curriculum intervention will reserve more political knowledge.

Study hypothesis IV: the political communications of students receiving curriculum intervention possess comprehension orientation.

\section{STUDY ACHIEVEMENTS}

\section{A. The Difference on Sexes of College Students' Political Engagement}

Conduct single-factor variance analysis to the "political attention", "degree of satisfaction of political engagement", "self-confidence degree of engagement in political conversation". "Political knowledge reserve" and the tendency (comprehension type/strategy type) of using learned contents in "political conversation" of college students on the aspect of sex. And it is shown in the results that the difference in dimensionality of above political engagement is not obvious on the aspect of $\operatorname{sex}(\mathrm{F}$ attention $[1,79]=0.185 ; \mathrm{p}>.05 ; \mathrm{F}$ political engagement skill $[1,79]=0.293 ; \mathrm{p}>.05 ; \mathrm{F}$ Self-confidence $[1,79]=0.766$; $\mathrm{p}>.05 ; \mathrm{F}_{\text {Inner political efficacy }}[1,79]=0.177 ; \mathrm{p}>.05 ; \mathrm{F}$ knowledge reserve $[1,79]=0.522 ; \mathrm{p}>.05 ; \mathrm{F}$ comprehension type $[1,79]=0.293 ; \mathrm{p}>.05 ; \mathrm{F}$ strategy type $[1,79]=0.979 ; \mathrm{p}>.05)$ which means that there is no significant difference in the political engagement of college male and female students.

\section{B. Assessment on the Impacts of Implementation of Theme CYL Day Activity}

After implementation of theme CYL Day activity, a series of variance analysis has been conducted to the control class and experimental class in this study on multiple factors (related dimensionality of political engagement). It can be seen from table 1 that the manifestation of other political engagement of experimental class is significantly higher than that of control class except the aspects of "political knowledge reserve" and "tendency of political conversation (strategy type)".

Meanwhile, this study takes curriculum intervention a(control class/experimental class) as independent variable while takes the dimensionality including "political attention", "degree of satisfaction of political engagement skill", "selfconfidence degree of engagement in political conversation", etc indicating political engagement as dependent variable. The study adopts regression analysis to explore whether the implementation of theme CYL Day activity possesses predictive effect to the corresponding political engagement of college students. It can be seen in table 3 that the implementation of theme CYL Day activity possesses significant predictive effects to the "political attention", "degree of satisfaction of political engagement skill", "selfconfidence degree of engagement in political conversation", "inner political efficacy" and the comprehension-type tendency manifested in using the learned contents in "political conversation". This also demonstrates "study hypothesis I", "study hypothesis II", "study hypothesis III" and "study hypothesis IV". Because the content "the students receiving theme CYL Day activity will reserve more political knowledge" is not manifested in "Table II" and "Table III", the "study hypothesis III" will not be established.

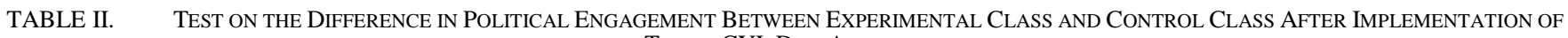
THEME CYL DAY ACITVITY

\begin{tabular}{|c|c|c|c|c|c|}
\hline & \multicolumn{2}{|c|}{ Control Class $(N=41)$} & \multicolumn{2}{|c|}{ Experimental Class $(N=40)$} & \multirow[b]{2}{*}{$\boldsymbol{F}$} \\
\hline & $M$ & $S D$ & $M$ & $S D$ & \\
\hline Political attention & 5.075 & 1.309 & 6.098 & 1.357 & $11.914 * * *$ \\
\hline Degree of satisfaction of political engagement skill & 2.350 & 0.834 & 2.951 & 0.631 & $13.445 * * *$ \\
\hline $\begin{array}{l}\text { Self-confidence degree of engagement in political } \\
\text { conversation }\end{array}$ & 2.175 & 0.636 & 2.683 & 0.820 & $9.675 * *$ \\
\hline Inner political efficacy & 2.075 & 0.971 & 3.049 & 1.048 & $18.800 * * *$ \\
\hline Tendency of political conversation (comprehension type) & 24.675 & 3.996 & 26.976 & 3.205 & $8.189 * *$ \\
\hline Tendency of political conversation (strategy type) & 8.800 & 1.067 & 9.342 & 2.093 & 2.135 \\
\hline Political knowledge reserve & 3.750 & 1.428 & 3.756 & 1.463 & 0.000 \\
\hline
\end{tabular}




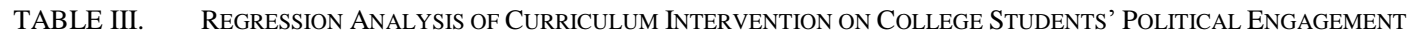

\begin{tabular}{|c|c|c|c|c|c|}
\hline Independent Variable & Dependent Variable & $R^{2}$ & $\boldsymbol{F}$ & $\boldsymbol{B}$ & $t$ \\
\hline \multirow{10}{*}{$\begin{array}{l}\text { Curriculum intervention (control } \\
\text { class/experimental class) }\end{array}$} & Political attention & 0.131 & $5.897 * * *$ & -.050 & -.165 \\
\hline & \multirow{2}{*}{ Degree of satisfaction of political engagement skill } & \multirow{2}{*}{0.154} & \multirow{2}{*}{$7.085 * * *$} & -.145 & -.874 \\
\hline & & & & 0.589 & $3.573 * * *$ \\
\hline & Self-confidence degree of engagement in political conversation & 0.117 & $5.173^{* * *}$ & 0.139 & 0.840 \\
\hline & \multirow{2}{*}{ Inner political efficacy } & \multirow{2}{*}{0.192} & \multirow{2}{*}{$9.282^{* * *}$} & -0.010 & -.045 \\
\hline & & & & 0.973 & $4.289 * * *$ \\
\hline & Tendency of political conversation (comprehension type) & 0.111 & $4.855^{* *}$ & $\begin{array}{l}-0.985 \\
2.217\end{array}$ & $\begin{array}{l}-1.213 \\
2.756^{* *}\end{array}$ \\
\hline & \multirow{2}{*}{ Tendency of political conversation (strategy type) } & \multirow{2}{*}{0.042} & \multirow{2}{*}{1.707} & 0.423 & 1.128 \\
\hline & & & & 0.577 & 1.555 \\
\hline & Political knowledge reserve & 0.007 & 0.261 & 0.236 & 0.722 \\
\hline
\end{tabular}

\section{ANALYSIS AND DISCUSSION}

The serial theme CYL Day activity provides the opportunity for individual constructive leaning for the college students' political engagement and also let them review their acquired related skills (such as civil skills and political affair discussion) which have positive impacts on their political engagement. The analysis on detailed reasons is as follow:

The first is enhancement of inner political efficacy of college students. The political efficacy is the ability of individual of considering that their engagement will impact political systems and government decisions. The political efficacy possess double dimensionality- inner and external political efficacy[16]. The external political efficacy refers to the confidence degree of individuals on the condition where government will respond to the political appeals of citizens while the inner political efficacy refers to the ability of individual on considering that they will exert impacts on politics. The participants feel relatively satisfied with their manifestation in CYL Day activity, consider that they have the ability of engagement in political activities and will be aware of their functions in engaging in political and government affairs. The implementation of CYL Day activity provides the structural political information method to students and the opportunity for them to develop political conversation with others. Currently, the young students are mostly exposed in the conditions of medium political discussion and lack the political conversation in real conditions. The face-to-face conversation mode adopted in the CYL Day activity curriculum in the study let students directly feel the authenticity of political engagement and conduct direct and effective assessment to their political engagement and discussion abilities. While the participants with higher inner political efficacy prove their abilities of political engagement and discussion in theme CYL Day activities and further enhance or promote their abilities and will possibly guide the political engagement and behaviors during this process.

The second is the enhancement of political consciousness and political attention of college students. The stronger the individual political consciousness and political attention are, the individuals will better generate perceptivity of certain consciousness which means that they will much more believe that they have the abilities of participating in the political activities so as to trigger the individual political engagement[17]. The space openness of political engagement in CYL Day activity can promote the individual attention on political and government affairs. Compared with students in control class, those who participate in CYL Day activity show stronger attention. For the college students who have not formed the fixed political engagement, the political consciousness is a special and important measurement index. As the composition of political consciousness- "cognitive engagement" can trigger further political engagement. When some of the political engagement behaviors are rear, the political attention and interest of individuals will possibly trigger other extra political engagement behaviors.

The third is the improvement of college students' political identification. The formation of political identification means the political learning and conducts based on political belief of individuals [18]. From the inner mechanism of college students' political engagement and promotion of identification, it is mainly the enhancement of mechanism of formation of political decisions and sense of determination of basic elements of college students. The attitude is the focus of study on political behaviors. And the cognition behind attitude is receiving more and more attention. The simplest form of such cognition is political facts which refer to the various information segments about politics held by citizens. Thereinto, the political knowledge includes basic political knowledge (such as the operation mechanism of political institutions) and current important political news, while, the level of political knowledge possessed by individuals can forecast the occurrence rate of their political engagement behaviors. Although the study achievements do not indicate that students learn more political knowledge during the whole CYL Day activity process, the political knowledge involved with political conversation and debate links participated by students lets them have deeper understanding of political system, polity and values as well as systems and clearer recognition of the mechanism and basic elements for political decision formation through structuring of curriculum contents so as to promote their political identification and trigger more political engagement behaviors.

The fourth is the acquisition of political engagement skills. Facing the dispute incurred by political engagement and conflicts in mutual compromise and among various parties, most of college students usually do not know what to do. 
Currently, the colleges focus much more on the students' participation in campus democratic management and encourage them to use the measure of democratic consultation to discuss and solve problems. As the identity of political dialogist, the college students are still in green hands level on the aspects of negotiation skills and knowledge reserve, therefore there will possibly be certain immature realism which will further form the indifference and antipathy toward politics and political systems. There are studies indicating that the explicit negotiation mode full of skills will facilitate to changing the condition of political indifference[20]. Therefore, this study specially integrates the methods and strategies that are learned and developed in the political engagement of students in the theme CYL Day activity curriculum, and takes the promotion of conservation and understanding as objectives. The teaching of such methods and strategies will exactly help college students obtain the method of others to discuss the universal recognition of politics and give them the tools for cautiously making decisions which is to facilitate them on how to build and discuss the political agendas with complex conditions.

\section{CONCLUSION}

The study shows that the teaching and learning about political information and conversation have positive impacts on the political attention, political efficacy and self-confidence degree of college students. The clear curriculum teaching structure and interactive teaching mode will let students form the political identification and the social network with the topic of political conversation and discussion. The current college first class teaching and campus culture activity cannot let college students participate relatively more activities related to politics, therefore the reset of political discussion mode and construction of social network with the topic of political interaction are of great importance to the cultivation of political sense of mission and political identification of college students. Because this study takes the CYL Day activity as curriculum setting platform, the future studies may be expanded in the first classes, especially the ideological and political lessons. We can try to set up the teaching links with strong engagement and interactivity and design more suitable activities through development of discussion and providing concept frameworks and strategies to let students learn knowledge in experience and motivate more political engagement of college students.

Meanwhile, the college educators shall clear up the behavior modes of college students for discussion and engagement of politics and teach students to convert the discussion skills into unknown conditions. Although the study adopts objective investigation and survey, the educators still need more listening, attention and understanding for the political conversation incurred in student groups. This study illuminates that the orientation of development of political discussion of students is mainly comprehension type and provides the educators with examples used to encourage students to develop successful political conversation. To enable the students to transfer the opinions and strategies learned to the future political conversation, the college teachers may try to add the reflection link in the classes or after classes such as letting students write diaries or reflective essays so as to detail the adoption conditions for the skills and strategies learned before of various items, conclude important principles and imagine the difficulties that must be overcome in the future political engagement process.

Of course, there are certain limitations in this study which is also the issue that needs to be broken through in the future studies. The first is that the study mainly relies on self-report survey and fails in obtaining more objective survey. Therefore, the students may turn out to be over optimistic over their roles played in political activities and the degree of proficiency of skill application; the second is the finiteness of sample quantity. Although the designed study proves the impacts of CYL Day activity curriculum, there are still the needs of conducting repetitive studies with larger sample quantity so as to improve the reliability and validity of studies; the third is the failure of exploring the longitudinal variation of subjects. We should further investigate the validity of such curriculum intervention in the conditions of citizen learning, strategy of development and organizational opportunity which is also the important content in the study on long-term development of college students' political engagement.

\section{REFERENCES}

[1] Zhang Haibo. Political Engagement of Contemporary College Students: Comparison between Two Modes of Reality and Network, published on Nanjing Journal of Social Sciences, Volume 9, 2011.

[2] Hollander, E. Civic Education In Research Universities: Leaders Or Followers. Education \& Training, 2011, 53: 166-176.

[3] S.Gillmor. Differential outcomes for American college students engaged in community service learning involving youth and adults. Journal of Experiential Education, 2012, 35: 447-463.

[4] D.Simpson. Teaching Civic Engagement: From Student to Active Citizen. Washington, DC: American Political Science Association, 2013

[5] Klofstad, C. 2010. The Lasting Effect of Civic Talk on Civic Participation: Evidence from a Panel Study. Social Forces, 2010, 88: 2353-2376.

[6] Schamber, J. \& S. Mahoney. The Development of Political Awareness and Social Justice Citizenship through Community-Based Learning in a First-Year General Education Seminar. Journal of General Education, 2008, 57: 75-99.

[7] Mariani, M. The Effect of Campaign Internships on Political Efficacy and Trust. Journal of Political Science Education,2009, 5:275-293.

[8] Xu Hua. Analysis on Political Belief and Current Situation of Political Engagement of 90s College Students- Based on Investigation of Colleges in Anhua, published on Journal of China Youth University of Political Sciences, Volume 4, 2010.

[9] Wu Taisheng. Practical Consideration and Situation Expectations of College Students, published on China Youth Study, Volume 1, 2010.

[10] Tang Guozhan. Investigation and Thinking of Political Engagement Modes of Contemporary College Students- A Case Study of Henan Colleges, published on Henan Social Sciences, Volume 4, 2010.

[11] Zou Jingqin. Investigation of Online Political Engagement of College Students and Construction of Standard Mechanism- An Empirical Case Study of Eight Colleges in Guangdong, published on Study of Politics, Volume 4, 2010.

[12] Sun Dawei. Empirical Study of Online Democratic Participation Features of Contemporary College Students, published on Leadin Journal of Ideological and Theoretical Education, Volume 12, 2012.

[13] Ji Haiju. Study on the Online Political Engagement of College Students in New Media Time and the Development Trend, published on Nanjing Journal of Social Sciences, Volume 7, 2014. 
[14] Li Haiying. Study on Problems Existing in College CYL Day Activity and Solutions, published on Master's Thesis of Hebei Normal University, 2011.

[15] Longo, N. The New Student Politics: Listening to the Political Voice of Students . Journal of Public Affairs, 2004, 7: 61-74.

[16] Balch, G. I.Multiple Indicators in Survey Research: The Concept 'Sense of Political Efficacy. Political Methodology,1974, 12: 1-43.

[17] Pasek, J.Schools as Incubators of Democratic Participation: Building Long-Term Political Efficacy with Civic Education. Applied Developmental Science, 2008, 12: 26-37.

[18] Colby, A. Educating for Democracy: Preparing Undergraduates for Responsible Political Engagement. San Francisco: Jossey-Bass, 2007, 322-324.

[19] Delli Carpini, M. X. \& S. Keeter. Measuring Political Knowledge: Putting First Things First. American Journal of Political Science, 1993, 37: 1179-1206.

[20] Hibbing, J. \& E. Theiss-Morse. Stealth Democracy: Americans' Beliefs about How Government Should Work. Cambridge: Cambridge University Press, 2002, 443-456. 